\title{
RESPON PERTUMBUHAN DAN PRODUKSI TANAMANKEDELAI (Glycine max L.) TERHADAP PEMBERIAN DOSIS PUPUK N DAN PUPUK KANDANG SAPI
}

\section{Pantas Simanjuntak ${ }^{\bowtie}$, Parsaoran Sihombing, Teddy Pernando Simarmata}

Fakultas Pertanian, Universitas Methodist Indonesia, Medan, Indonesia Email: simanjuntak.pantas@gmail.com

\section{DOI: https://doi.org/10.46880/methoda.Vol11No1.pp60-74}

\begin{abstract}
Soybean (Glycine max L) is a potential agricultural commodity to be developed in Indonesia. Soybeans have a high protein content which is beneficial for health. Nitrogen fertilizers and cow manure are often used to increase crop production. The purpose of the study was to determine the effect of the dose of $N$ fertilizer and cow manure on the growth and production of soybean (Glycine max L.). The research was conducted at the Regional Technical Service Unit (UPTD) of Palawija Seeds, Tanjung Selamat Jalan Pendidikan, Medan Sunggal, Deli Serdang, North Sumatra with an altitude of \pm 30 meters above sea level ( $m$ asl). The study was conducted using a factorial randomized block design (RAK) which consisted of 2 treatment factors, namely: The first factor was $N$ fertilizer consisting of 4 concentration levels, namely: $P 0=$ Control, $P 1=N$ fertilizer dose $15 \mathrm{gr} /$ plot $(150$ $\mathrm{kg} / \mathrm{ha}), P 2=$ Dosage of $N$ fertilizer $30 \mathrm{gr} / \mathrm{plot}(300 \mathrm{~kg} / \mathrm{ha}), P 3=$ Dose of $N$ fertilizer $45 \mathrm{gr} /$ plot (450 kg/ha). The second factor is cow manure $(\mathrm{K})$ with 3 dose levels, namely: $K 1=1 \mathrm{~kg} /$ plot (10 tons $/ \mathrm{ha}), \mathrm{K} 2=1.5 \mathrm{~kg} / \mathrm{plot}(15 \mathrm{tons} / \mathrm{ha}), \mathrm{K} 3=2 \mathrm{~kg} / \mathrm{plot}$ (20 tons/ha). The results showed that fertilizer $N$ had a significant effect on plant height, number of empty pods per sample, number of filled pods per sample, seed weight per sample, seed weight per plot and weight of 100 seeds but had no significant effect on flowering age. Cow manure had a significant effect on the number of empty pods per sample, seed weight per sample and seed weight per plot but had no significant effect on plant height, flowering age, number of filled pods per sample and weight of 100 seeds. The interaction of $N$ fertilizer and cow manure had no significant effect on plant height, flowering age, number of empty pods per sample, number of filled pods per sample, seed weight per sample, seed weight per plot and weight of 100 seeds.
\end{abstract}

Keywords: Nitrogen, Cow Manure, Soybean.

\section{ABSTRAK}

Kedelai (Glycine max ) merupakan suatu komoditas pertanian yang potensial untuk dikembangkan di Indonesia. Kedelai memiliki kandungan protein yang tinggi yang bermanfaat bagi kesehatan. Pupuk Nitrogen dan Pupuk kandang sapi sering digunakan untuk meningkatkan produksi tanaman. Tujuan penelitian adalah untuk mengetahui pengaruh pemberian dosis pupuk $\mathrm{N}$ dan pupuk kandang sapi terhadap pertumbuhan dan 
produksi tanaman kedelai (Glycine max L.). Penelitian dilakukan di Unit Pelayanan Teknis Daerah (UPTD) Benih Induk Palawija Tanjung Selamat Jalan Pendidikan, Medan Sunggal, Deli Serdang, Sumatera Utara dengan ketinggian tempat \pm 30 meter di atas permukaan laut (m dpl). Penelitian dilakukan dengan menggunakan Rancangan Acak Kelompok (RAK) Faktorial yang terdiri dari 2 faktor perlakuan yaitu: Faktor pertama adalah pupuk $\mathrm{N}$ terdiri dari 4 taraf konsentrasi yaitu: $\mathrm{P} 0=$ Kontrol, $\mathrm{P} 1=$ Dosis pupuk N $15 \mathrm{gr} /$ plot (150 kg/ha), P2 = Dosis pupuk N $30 \mathrm{gr} /$ plot (300 kg/ha), P3 = Dosis pupuk N $45 \mathrm{gr} /$ plot (450 kg/ha). Faktor kedua adalah pupuk kandang sapi (K) dengan 3 taraf dosis, yaitu: $\mathrm{K} 1=1 \mathrm{~kg} /$ plot (10 ton $/ \mathrm{ha}), \mathrm{K} 2=1.5 \mathrm{~kg} / \mathrm{plot}$ (15 ton $/ \mathrm{ha}), \mathrm{K} 3=2$ $\mathrm{kg} /$ plot (20 ton/ha). Hasil penelitian menunjukkan bahwa pupuk $\mathrm{N}$ berpengaruh nyata terhadap tinggi tanaman, jumlah polong hampa per sampel, jumlah polong berisi per sampel, bobot biji per sampel, bobot biji per plot dan bobot 100 biji tetapi berpengaruh tidak nyata terhadap umur berbunga. Pupuk kandang sapi berpengaruh nyata terhadap jumlah polong hampa per sampel, bobot biji per sampel dan bobot biji per plot tetapi berpengaruh tidak nyata terhadap tinggi tanaman, umur berbunga, jumlah polong berisi per sampel dan bobot 100 biji. Interaksi pupuk $\mathrm{N}$ dan pupuk kandang sapi berpengaruh tidak nyata terhadap tinggi tanaman, umur berbunga, jumlah polong hampa per sampel, jumlah polong berisi per sampel, bobot biji per sampel, bobot biji per plot dan bobot 100 biji.

Kata Kunci: Nitrogen, Pupuk Kandang Sapi, Kedelai.

\section{PENDAHULUAN}

Konsumsi masyarakat Indonesia tahun 2010-2014 kebutuhan kedelai setiap tahunnya \pm 2.300.000-ton biji kering (Ditjen Tanaman Pangan, 2013), berbanding terbalik dengan kemampuan produksi. Ketidakstabilan produksi kedelai di Indonesia disebabkan oleh beberapa faktor: (1) Adanya penurunan luas panen kedelai yang tidak diimbangi dengan peningkatan produktivitas kedelai. (2) Penggunaan pupuk kimia yang secara terusmenerus yang tidak di imbangi dengan penggunaan pupuk organik oleh parapetani, yang menyebabkan terjadinya penurunan kesuburan tanah (Fachruddin, 2000). Pemberian pupuk anorganik yang berlebihan ketika melakukan budidaya tanaman, dapat menyebabkan degradasi tanah, karena perubahan sifat fisik tanah, seperti terjadinya pemadatan tanah, perubahan struktur tanah, menurunkan jumlah organisme tanah yang bermanfaat untuk mendekomposisi bahan organik, serta terjadinya penurunan kandungan unsur hara di dalam tanah (Triyono, 2013).

Untuk memperbaiki degradasi tanah dapat dilakukan dengan pemberian pupuk organik seperti pupuk kandang. Pupuk kandang terdiri dari campuran antara kotoran hewan dengan sisa makanan dan alas tidur hewan. Campuran ini mengalami pembusukan hingga tidak berbentuk seperti asalnya lagi dan memiliki kandungan hara yang cukup untuk menunjang pertumbuhan tanaman (Rodina, 2014). Diantara jenis pupuk kandang, pupuk kandang sapi yang mempunyai kadar serat yang tinggi seperti selulosa, dapat memperbaiki sifat fisika, kimia dan biologi tanah yaitu menyediakan unsur hara makro dan mikro bagi tanaman, menggemburkan tanah, memperbaiki struktur tanah, meningkatkan daya pegang air, meningkatkan kapasitas tukar kation, porositas, dan komposisi mikroorganisme dalam tanah, memudahkan pertumbuhan akar tanaman (Melati \& Andriyani, 2005; Rohmah, 2016). 
Nitrogen merupakan salah satu faktor kunci yang membatasi pertumbuhan dan perkembangan tanaman. Nitrogen juga menjadi salah satu unsur hara esensial yang sangat diperlukan oleh tanaman dalam jumlah yang cukup banyak. Hal ini disebabkan nitrogen mempunyai peran sangat penting bagi pertumbuhan, diantaranya adalah: (1) Sebagai penyusun klorofil: (2) Sebagai unsur penyusun asam amino: (3) Sebagai pembentukan protein, dan enzim. Kekurangan unsur ini akan memperlihatkan gejala klorosis yang ditandai dengan menguningnya daun. Menguningnya daun tersebut akan mengakibatkan menurunnya laju fotosintesis tanaman. Nitrogen yang berlimpah dapat meningkatkan pertumbuhan dengan cepat terutama pada batang, daun-daun menjadi hijau gelap dan tanaman menjadi sekulen sehingga mudah hama dan penyakit (Purbajanti \& Kusmiyati, 2013). Oleh karena itu, maka dilakukan penelitian tentang respon pertumbuhan dan produksi tanaman kedelai (Glycine max L.) terhadap pemberian dosis pupuk $\mathrm{N}$ dan pupuk kandang sapi.

\section{METODE PENELITIAN}

Penelitian ini dilakukan di UPTD Benih Induk Palawija Tanjung Selamat Jalan Pendidikan, Medan Sunggal, Deli Serdang, Sumatera Utara dengan ketinggian tempat \pm 30 meter di atas permukaan laut (mdpl). Penelitian ini di laksanakan pada bulan Desember 2019 sampai dengan bulan Maret 2021. Bahan yang digunakan dalam penelitian ini adalah benih kacang kedelai Varietas Anjasmoro, pupuk kandang sapi, pupuk urea, pupuk hayati Rhizobium, dan air. Alat yang di gunakan dalam penelitian ini adalah cangkul, parang, meteran, gembor, tali rafia bambu, timbangan, plank perlakuan, kalkulator, alat tulis, penggaris dan alat-alat lain yang mendukung dalam pelaksanaan peneltian ini.

\section{Penelitian menggunakan Rancangan} Acak Kelompok (RAK) Faktorial yang terdiri dari 2 faktor perlakuan yaitu: Faktor pertama adalah pupuk N (Urea) terdiri dari 4 taraf yaitu:P0 = Kontrol; P1 = Dosis pupuk $\mathrm{N} 15 \mathrm{gr} /$ plotP2 = Dosis pupuk N $30 \mathrm{gr} /$ plot P3 = Dosis pupuk N 45 g/plot. Faktor kedua adalah pupuk kandang sapi (K) dengan 3 taraf, yaitu: K1 = Takaran pupuk kandang sapi $1 \mathrm{~kg} /$ plot. K2 = Takaran pupuk kandang sapi $1,5 \mathrm{~kg} /$ plotK3 = Takaran pupuk kandang sapi $2 \mathrm{~kg} /$ plot.Jumlah kombinasi perlakuan adalah $4 \times 3=12$ yaitu:

Bedengan dibuat dengan ukuran $100 \mathrm{x}$ $100 \mathrm{~cm}$, dengan jarak antar plot $35 \mathrm{~cm}$ dan jarak antar ulangan $70 \mathrm{~cm}$, kemudian dibuat drainase untuk mencegah genangan air pada musim hujan. Pemberian pupuk kandang sapi diberikan 1 Minggu Sebelum Tanam (MST). Benih terlebih dahulu direndam dengan air, lalu diberikan dan dicampur dengan pupuk hayati Rhizobium. Benih kacang kedelai di tanam dengan kedalaman 2-3 cm, kemudian ditutupi dengan tanah agar tidak di ganggu semut atau hama lainnya. Pemberian pupuk nitrogen dilakukan dengan cara diberikan sebanyak 2 kali yaitu saat tanam umur 15 dan 30 Hari Setelah Tanam (HST). Penyiraman dilakukan dengan menggunakan air dan disiramkan dengan menggunakan gembor. Penyiraman dilakukan setiap hari sebanyak 2 kali sehari, kecuali apabila turun hujan maka penyiraman pada tanaman tidak dilakukan.

\section{HASIL DAN PEMBAHASAN:}

\section{Tinggi Tanaman (cm).}

Parameter tinggi tanaman kedelai berpengaruh nyata (Tabel 1.) terhadap pupuk nitrogen karena fungsi unsur hara nitrogen bagi tanaman adalah merangsang 
pertumbuhan vegetatif tanaman khususnya akar, batang dan daun. Unsur hara $\mathrm{N}$ ini terdapat dalam jumlah yang kurang maka aktivitas metabolisme yang terkait akan terganggu dan akhirnya pertumbuhan tanaman akan terhambat serta hasil tanaman akan menjadi rendah (Nurherliani, Ningsih, \& Mawarni, 2019). Fungsi unsur nitrogen bagi tanaman adalah sebagai penyusun protein dan klorofil. Pembentukan klorofil berguna dalam proses fotosintesis, dimana unsur ini berperan sebagai sintesis klorofil (Permadi \& Haryati, 2015). Klorofil berfungsi untuk menangkap cahaya matahari yang berguna untuk pembentukan makanan dalam proses fotosintesis. Hasil dari fotosintesis akan digunakan oleh tanaman untuk pertumbuhan generatif tanaman seperti pembentukan polong tanaman.

Tabel 1. Uji Beda Rataan Tinggi Tanaman Kedelai (cm) akibat Perlakuan Pupuk N dan Pupuk Kandang Sapi pada Umur 14, 21, 28 dan 35 HST

\begin{tabular}{lllll}
\hline Perlakuan & \multicolumn{5}{l}{ Tinggi Tanaman $(\mathrm{cm})$} & \\
\cline { 2 - 5 } Pupuk N & $14 \mathrm{HST}$ & $21 \mathrm{HST}$ & $28 \mathrm{HST}$ & $35 \mathrm{HST}$ \\
\hline P0 & 18.31 & 24.20 & $35.94 \mathrm{~b}$ & $47.82 \mathrm{~b}$ \\
P1 & 18.62 & 25.71 & $39.33 \mathrm{a}$ & $56.69 \mathrm{a}$ \\
P2 & 18.93 & 26.75 & $41.37 \mathrm{a}$ & $59.76 \mathrm{a}$ \\
P3 & 18.56 & 25.84 & $40.65 \mathrm{a}$ & $58.39 \mathrm{a}$ \\
\hline Pukan Sapi & & & & \\
K1 & 18.21 & 24.98 & 38.13 & 53.78 \\
K2 & 18.53 & 25.31 & 39.08 & 55.79 \\
K3 & 19.09 & 26.59 & 40.75 & 57.43 \\
\hline Kombinasi & & & & \\
P0K1 & 17.39 & 23.52 & 34.70 & 46.44 \\
P0K2 & 18.41 & 24.31 & 35.89 & 47.94 \\
P0K3 & 19.14 & 24.78 & 37.22 & 49.07 \\
P1K1 & 18.20 & 25.09 & 37.72 & 54.06 \\
P1K2 & 18.51 & 25.39 & 39.78 & 57.94 \\
P1K3 & 19.16 & 26.66 & 40.50 & 58.08 \\
P2K1 & 18.41 & 26.10 & 39.94 & 58.11 \\
P2K2 & 18.86 & 26.14 & 40.28 & 58.39 \\
P2K3 & 19.52 & 28.02 & 43.89 & 62.78 \\
P3K1 & 18.82 & 25.19 & 40.17 & 56.50 \\
P3K2 & 18.33 & 25.41 & 40.39 & 58.89 \\
P3K3 & 18.53 & 26.91 & 41.40 & 59.78 \\
\hline KK & & & & \\
\hline
\end{tabular}

Keterangan: Angka yang diikuti oleh huruf yang sama pada kolom yang sama berbedatidak nyata pada taraf $\alpha=0.05$ berdasarkan uji jarak Duncan.

Kurva respon tinggi tanaman kedelai terhadap perlakuan pupuk $\mathrm{N}$ dapat dilihat pada Gambar 1, terlihat bahwa respon antara pupuk $\mathrm{N}$ dengan tinggi tanaman kedelai adalah kuadratik. Artinya, tinggi tanaman kedelai akan mengalami peningkatan hingga pemberian dosis $32,69 \mathrm{~g}$ pupuk $\mathrm{N}$. 


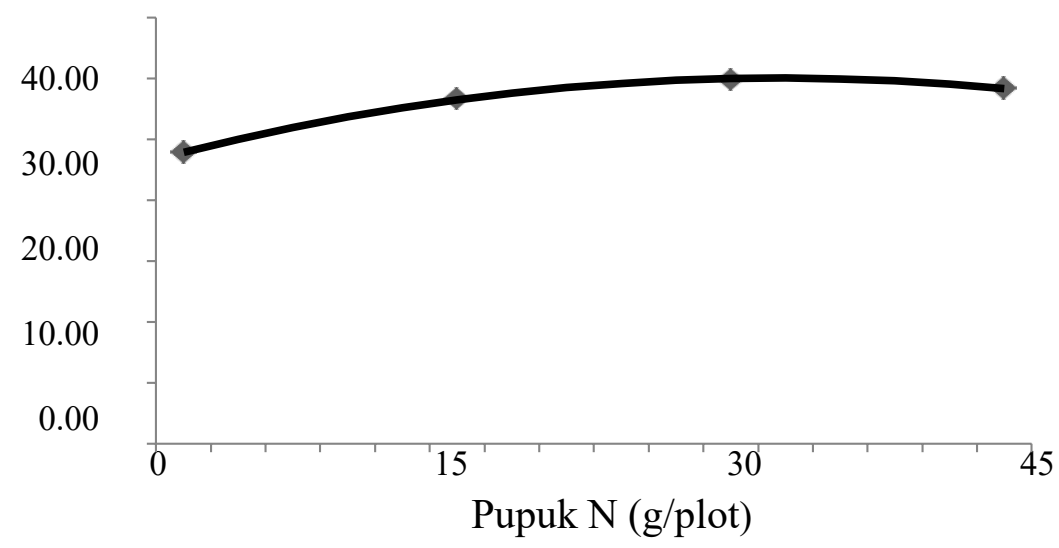

Gambar 1. Respon Tinggi Tanaman Kedelai pada umur 35 HST terhadap Perlakuan Pupuk.

\section{Umur Berbunga (Hari)}

Pupuk N dan pupuk kandang sapi berpengaruh tidak nyata terhadap umur berbunga tanaman kedelai. Interaksi antara pupuk $\mathrm{N}$ dan pupuk kandang sapi juga berpengaruh tidak nyata terhadap umur berbunga tanaman kedelai (Tabel 2)

Tabel 2. Uji Beda Rataan Umur Berbunga Tanaman Kedelai akibat Perlakuan Pupuk N dan Pupuk Kandang Sapi

\begin{tabular}{|c|c|c|c|c|c|}
\hline \multirow{3}{*}{$\begin{array}{l}\text { Perlakuan } \\
\text { Pukan Sapi }\end{array}$} & & $\mathrm{Pu}$ & & & \multirow{3}{*}{ Rataan } \\
\hline & P0 & $\mathrm{P} 1$ & $\mathrm{P} 2$ & $\mathrm{P} 3$ & \\
\hline & \multicolumn{4}{|c|}{...............Hari................ } & \\
\hline K1 & 36.00 & 35.67 & 35.67 & 35.67 & 35.75 \\
\hline K2 & 36.00 & 35.67 & 35.33 & 35.33 & 35.58 \\
\hline K3 & 35.67 & 35.33 & 35.00 & 35.33 & 35.33 \\
\hline Rataan & 35.89 & 35.56 & 35.33 & 35.44 & \\
\hline K1 & 36.00 & 35.67 & 35.67 & 35.67 & 35.75 \\
\hline $\mathrm{K} 2$ & 36.00 & 35.67 & 35.33 & 35.33 & 35.58 \\
\hline K3 & 35.67 & 35.33 & 35.00 & 35.33 & 35.33 \\
\hline Rataan & 35.89 & 35.56 & 35.33 & 35.44 & \\
\hline
\end{tabular}

Perlakuan pupuk $\mathrm{N}$ terhadap umur berbunga walaupun berpengaruh tidak nyata diperoleh rataan umur berbunga tercepat terdapat pada perlakuan P2. Perlakuan pupuk kandang sapi diperoleh rataan umur berbunga tercepat pada perlakuan K3.

\section{Jumlah Polong Hampa per Sampel}

Pupuk $\mathrm{N}$ dan pupuk kandang sapi berpengaruh nyata terhadap jumlah polong hampa per sampel tanaman kedelai.
Interaksi antara pupuk $\mathrm{N}$ dan pupuk kandang sapi berpengaruh tidak nyata terhadap jumlah polong hampa per sampel tanaman kedelai. Rataan jumlah polong hampa tanaman kedelai akibat pupuk $\mathrm{N}$ dan pupuk kandang sapi dapat dilihat pada Tabel 3 
Tabel 3. Uji Beda Rataan Jumlah Polong Hampa per Sampel Tanaman Kedelai akibat Perlakuan Pupuk N dan Pupuk Kandang Sapi

\begin{tabular}{llllll}
\hline Perlakuan & \multicolumn{5}{c}{ Pupuk N } \\
\hline Pukan & P0 & P1 & P2 & P3 & Rataan \\
Sapi & & & & & \\
K1 & 3.78 & 3.11 & 2.78 & 3.00 & $3.17 \mathrm{~b}$ \\
K2 & 3.78 & 2.78 & 2.11 & 2.11 & $2.69 \mathrm{a}$ \\
K3 & 2.11 & 2.44 & 1.00 & 1.56 & $1.78 \mathrm{a}$ \\
\hline Rataan & $3.22 \mathrm{a}$ & $2.78 \mathrm{a}$ & $1.96 \mathrm{~b}$ & $2.22 \mathrm{~b}$ & \\
\hline
\end{tabular}

Keterangan: Angka yang diikuti oleh huruf yang sama pada kolom yang sama berbeda tidak nyata pada taraf $\alpha=0.05$ berdasarkan uji jarak Duncan

Tabel 3 menunjukkan bahwa pengaruh perlakuan pupuk $\mathrm{N}$ terhadap jumlah polong hampa per sampel tanaman kedelai diperoleh rataan terbanyak terdapat pada perlakuan $\mathrm{P} 2$ berbeda nyata dengan $\mathrm{P} 0$ dan P1 tetapi berbeda tidak nyata dengan P3. Pengaruh perlakuan pupuk kandang sapi terhadap jumlah polonghampa per sampel tanaman kedelai diperoleh rataan terbanyak pada perlakuan K3berbeda nyata dengan $\mathrm{K} 1$ tetapi berbeda tidak nyata dengan K2. Kurva respon jumlah polong hampa per sampel tanaman kedelai terhadap perlakuan pupuk $\mathrm{N}$ dapat dilihat pada Gambar 2.

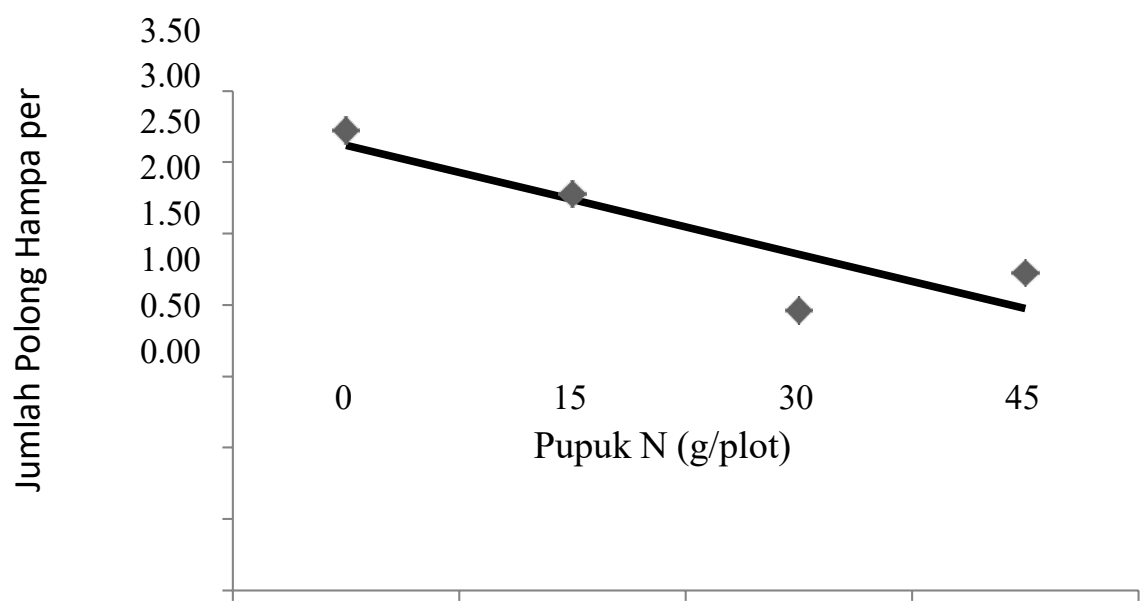

Gambar 2. Respon Jumlah Polong Hampa per Sampel Tanaman Kedelaiterhadap Perlakuan Pupuk N

Respon antara pupuk $\mathrm{N}$ dengan jumlah polong hampa per sampel tanaman kedelai adalah linier negative (Gambar 2). Artinya, jumlah polong hampa tanaman kedelai akan mengalami penurunan sejalan dengan semakin meningkatnya pupuk $\mathrm{N}$ yang diberikan. Demikian juga pupuk kandang sapi dengan jumlah polong hampa per sampel tanaman kedelai adalah linier negatif (Gambar 3). Artinya, jumlah 
polong hampa tanaman kedelai akan mengalami penurunan sejalan dengan

semakin meningkatnya pupuk kandang sapi yang diberikan.
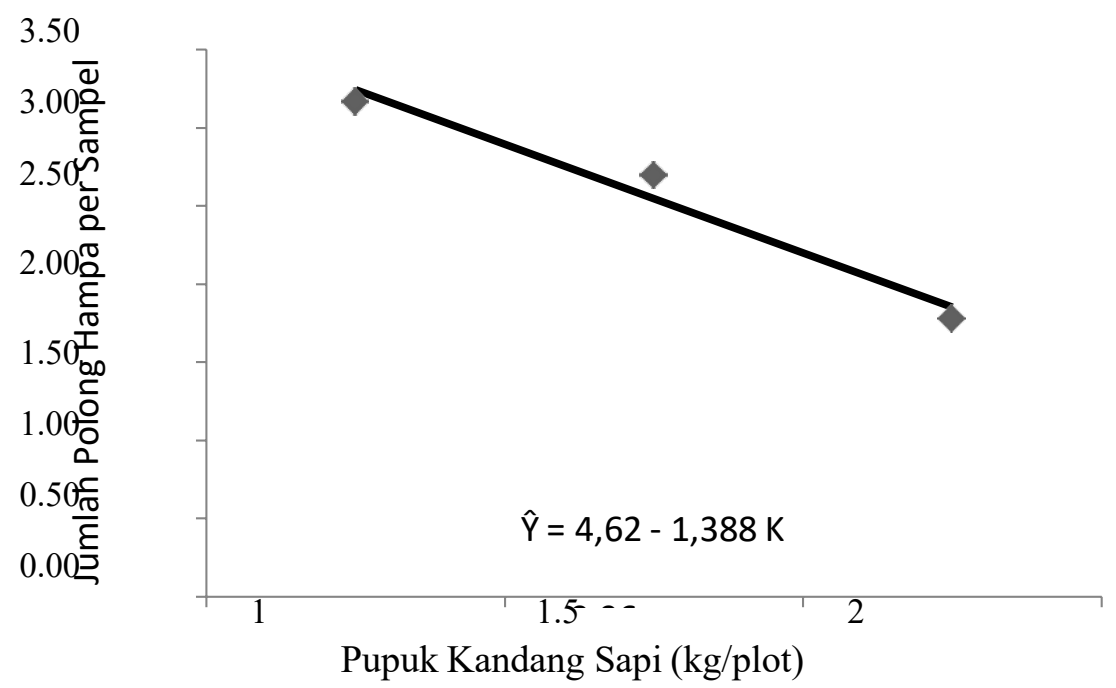

Gambar 3. Respon Jumlah Polong Hampa per Sampel terhadapPerlakuan Pupuk Kandang Sapi

\section{Jumlah Polong Berisi per Sampel}

Pupuk $\mathrm{N}$ berpengaruh nyata terhadap jumlah polong berisi per sampel tanaman kedelai. Perlakuan pupuk kandang sapi berpengaruh tidak nyata terhadapjumlah polong berisi per sampel. Interaksi antara pupuk $\mathrm{N}$ dan pupuk kandang sapi berpengaruh tidak nyata terhadap jumlah polong berisi per sampel tanaman kedelai. Rataan jumlah polong berisi tanaman kedelai akibat pupuk $\mathrm{N}$ dan pupuk kandang sapi dapat dilihat pada Tabel 4. Pengisian polong dan pembentukan biji sangat tergantung pada ketersediaan $\mathrm{N}$, baik $\mathrm{N}$ yang diambil oleh bakteri Rhizobium dari udara maupun $\mathrm{N}$ yang tersedia dalam tanah dan dipengaruhi juga oleh ketersediaan unsur P (Novriani, 2011). Ketersediaan N berada dalam kondisi seimbang akan mengakibatkan pembentukan asam amino dan protein meningkat dalam pembentukan biji sehingga polong terisi penuh. Unsur Nitrogen yang diserap tanaman melalui tanah, ditumpuk di bagian batang dan daun. $\mathrm{N}$ tersebut dihimpun ke dalam polong, setelah terbentuk polong, dengan semakin tua polong sebagian N (30-90\%) diserap ke dalam biji.

Tabel 4. Uji Beda Rataan Jumlah Polong Berisi per Sampel Tanaman Kedelai akibat Perlakuan Pupuk N dan Pupuk Kandang Sapi

\begin{tabular}{lccccr}
\hline Perlakuan & \multicolumn{5}{c}{ Pupuk N } \\
\hline Pukan Sapi & P0 & P1 & P2 & P3 & Rataan \\
K1 & 40.67 & 53.33 & 63.56 & 60.89 & 54.61 \\
K2 & 42.78 & 58.78 & 71.11 & 63.89 & 59.14 \\
K3 & 48.56 & 65.44 & 75.56 & 71.33 & 65.22 \\
\hline Rataan & $44.00 \mathrm{~b}$ & $59.19 \mathrm{a}$ & $70.07 \mathrm{a}$ & $65.37 \mathrm{a}$ \\
\hline
\end{tabular}

Keterangan: Angka yang diikuti oleh huruf yang sama pada kolom yang sama berbeda tidak nyata pada taraf $\alpha=0.05$ berdasarkan uji jarak Duncan. 
Pengaruh perlakuan pupuk $\mathrm{N}$ terhadap jumlah polong berisi per sampel tanaman kedelai diperoleh rataan terbanyak terdapat pada perlakuan P2 berbeda nyata dengan P0 tetapi berbeda tidak nyata dengan P1 dan P3. Pengaruh perlakuan pupuk kandang sapi terhadap jumlah polong berisi per sampel tanaman kedelai walaupun berpengaruh tidak nyata diperoleh rataan terbanyak pada perlakuan K3. Kurva respon jumlah polong berisiper sampel tanaman kedelai terhadap perlakuan pupuk $\mathrm{N}$ dapat dilihat pada Gambar 4



Gambar 4. Respon Pupuk terhadap jumlah Polong Berisi

Gambar 4 terlihat bahwa respon antara pupuk $\mathrm{N}$ dengan jumlah polong berisi tanaman kedelai adalah kuadratik. Artinya, jumlah polong berisi tanaman kedelai akan mengalami peningkatan hingga dosis 33,96 g pupuk $\mathrm{N}$ yang diberikan, setelah melebihi dosis tersebut maka jumlah polong berisi tanaman kedelai akan menurun kembali.

\section{Bobot Biji per Sampel (g)}

Pupuk $\mathrm{N}$ dan pupuk kandang sapi berpengaruh nyata terhadap bobot biji per sampel tanaman kedelai. Interaksi antara pupuk $\mathrm{N}$ dan pupuk kandang sapi berpengaruh tidak nyata terhadap bobot biji per sampel tanaman kedelai. Rataan bobot biji tanaman kedelai akibat pupuk $\mathrm{N}$ dan pupuk kandang sapi dilihat pada Tabel 5.

Tabel 5. Uji Beda Rataan Bobot Biji per Sampel Tanaman Kedelai akibat Perlakuan Pupuk N dan Pupuk Kandang Sapi

\begin{tabular}{lllllc}
\hline Perlakuan & \multicolumn{5}{c}{ Pupuk N } \\
\hline Pukan Sapi & P0 & P1 & P2 & P3 & Rataan \\
& & & & & \\
K1 & 13.00 & 17.89 & 19.89 & 22.06 & $18.21 \mathrm{~b}$ \\
K2 & 14.28 & 18.50 & 24.83 & 22.89 & $20.13 \mathrm{ab}$ \\
K3 & 15.22 & 22.80 & 25.50 & 23.94 & $21.87 \mathrm{a}$ \\
\hline Rataan & $14.17 \mathrm{c}$ & $19.73 \mathrm{~b}$ & $23.41 \mathrm{a}$ & $22.96 \mathrm{a}$ \\
\hline
\end{tabular}

Keterangan: Angka yang diikuti oleh huruf yang sama pada kolom yang sama berbedatidak nyata pada taraf $\alpha=0.05$ berdasarkan uji jarak Duncan 
Tabel 5 menunjukkan bahwa pengaruh perlakuan pupuk $\mathrm{N}$ terhadap bobot biji per sampel tanaman kedelai diperoleh rataan terberat terdapat pada perlakuan P2 berbeda nyata dengan P0 dan P1 tetapi berbeda tidak nyata dengan P3. Pengaruh perlakuan pupuk kandang sapi terhadap bobot biji per sampel tanaman kedelai diperoleh rataan terberat pada perlakuan K3 berbeda nyata dengan K1 tetapi berbeda tidak nyata dengan K2 Kurva respon bobot biji per sampel tanaman kedelai terhadap perlakuan pupuk $\mathrm{N}$ dapat dilihat pada Gambar 5.

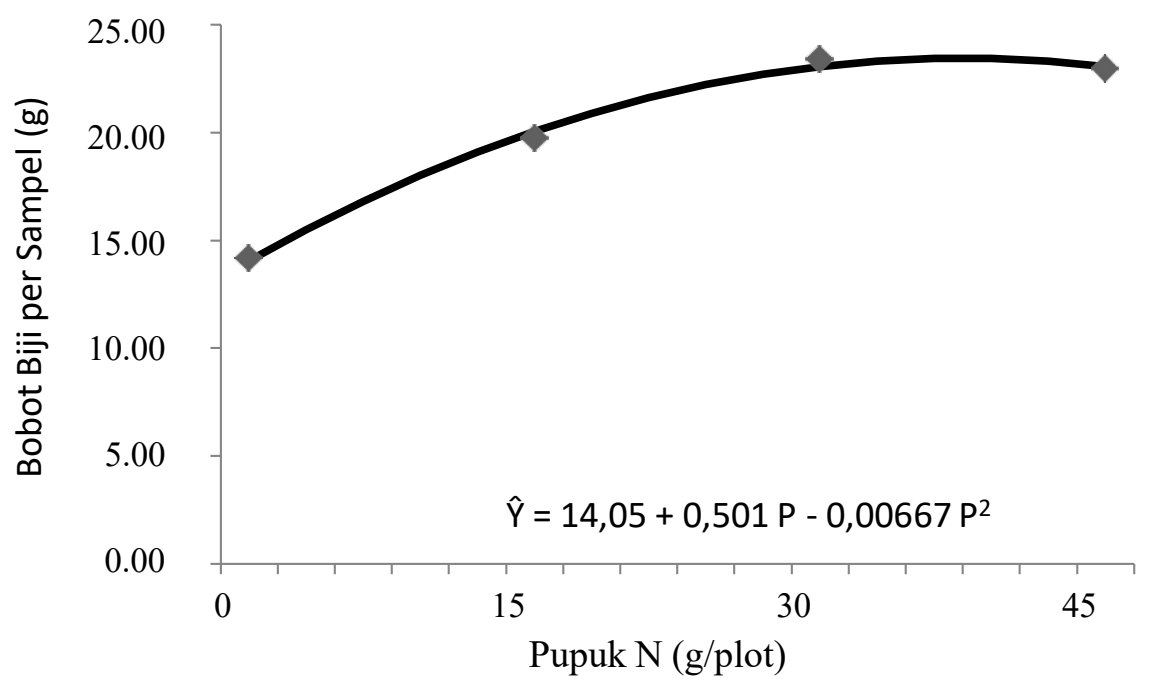

Gambar 5. Respon Bobot Biji per Sampel terhadap Perlakuan Pupuk N

Gambar 5 terlihat bahwa respon antara pupuk $\mathrm{N}$ dengan bobot biji per sampel tanaman kedelai adalah kuadratik. Artinya, bobot biji per sampel tanaman kedelai akan mengalami peningkatan hingga dosis 37,54 g pupuk $\mathrm{N}$ yang diberikan, setelah melebihi dosis tersebut maka bobot biji per sampel akan menurun kembali. Respon antara pupuk kandang sapi dengan bobot biji per sampel tanaman kedelai adalah linier positif (Gambar 6.).

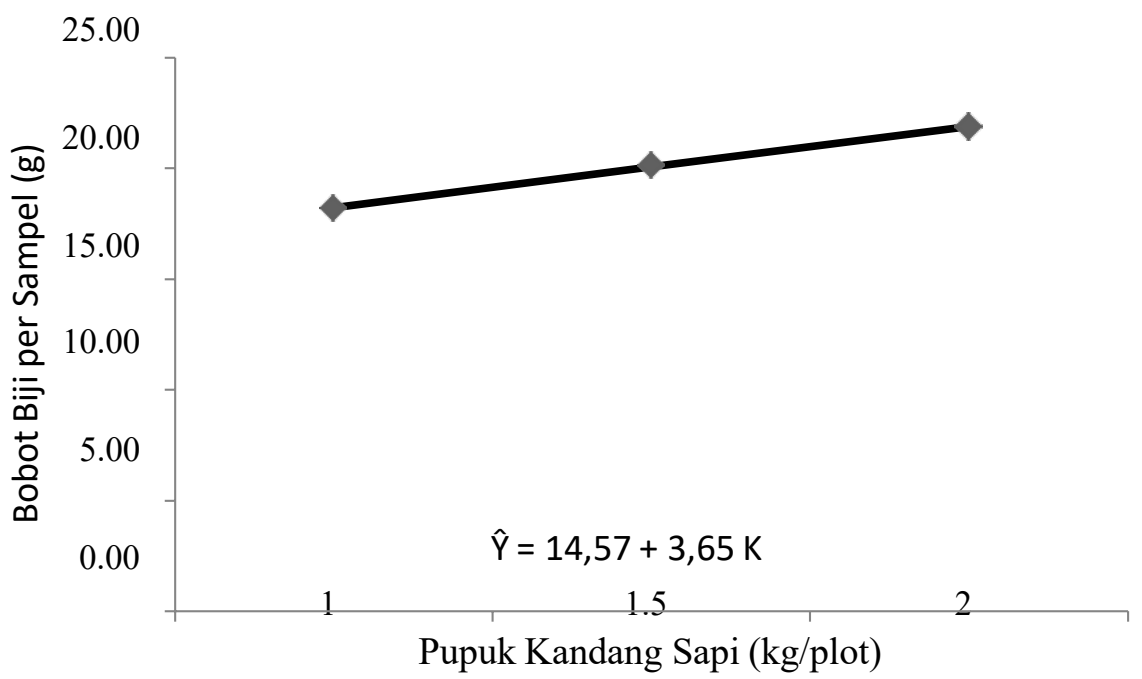

Gambar 6. Respon Bobot Biji per Sampel Tanaman Kedelai terhadap Perlakuan Pupuk Kandang Sapi. 


\section{Bobot Biji per Plot (g)}

Data bobot biji per plot tanaman kedelai akibat perlakuan pupuk $\mathrm{N}$ dan pupuk kandang sapi menunjukkan bahwa pupuk $\mathrm{N}$ dan pupuk kandang sapi berpengaruh nyata terhadap bobot biji per plot tanaman kedelai. Interaksi antara pupuk $\mathrm{N}$ dan pupuk kandang sapi berpengaruh tidak nyata terhadap bobot biji per plot tanaman kedelai. Rataan bobot biji tanaman kedelai akibat pupuk $\mathrm{N}$ dan pupuk kandang sapi dapat dilihat pada Tabel 6 .

Tabel 6. Uji Beda Rataan Bobot Biji per Plot Tanaman Kedelai akibat Perlakuan Pupuk N dan Pupuk Kandang Sapi

\begin{tabular}{lccccc}
\hline Perlakuan & \multicolumn{5}{c}{ Pupuk N } \\
\cline { 1 - 5 } Pukan Sapi & P0 & P1 & P2 & P3 & Rataan \\
K1 & 101.00 & 154.33 & 157.83 & 165.67 & $144.71 \mathrm{~b}$ \\
K2 & 102.00 & 162.17 & 183.17 & 180.83 & $157.04 \mathrm{ab}$ \\
K3 & 111.83 & 184.17 & 223.83 & 192.67 & $178.13 \mathrm{a}$ \\
\hline Rataan & $104.94 \mathrm{~b}$ & $166.89 \mathrm{a}$ & $188.28 \mathrm{a}$ & $179.72 \mathrm{a}$ \\
\hline
\end{tabular}

Keterangan: Angka yang diikuti oleh huruf yang sama pada kolom yang sama berbeda tidak nyata pada taraf $\alpha=0.05$ berdasarkan uji jarak Duncan

Tabel 6 menunjukkan bahwa pengaruh perlakuan pupuk $\mathrm{N}$ terhadap bobot biji per plot tanaman kedelai diperoleh rataan terberat terdapat pada perlakuan $\mathrm{P} 2$ berbeda nyata dengan $\mathrm{P} 0$ tetapi berpengaruh tidak nyata dengan P1 dan P3. Pengaruh perlakuan pupuk kandang sapi terhadap bobot biji per plot tanaman kedelai diperoleh rataan terberat pada perlakuan $\mathrm{K} 3$ berbeda nyata dengan $\mathrm{K} 1$ tetapi berbeda tidak nyata dengan K2. Kurva respon bobot biji per plot tanaman kedelai terhadap perlakuan pupuk $\mathrm{N}$ dapat dilihat pada Gambar 7.

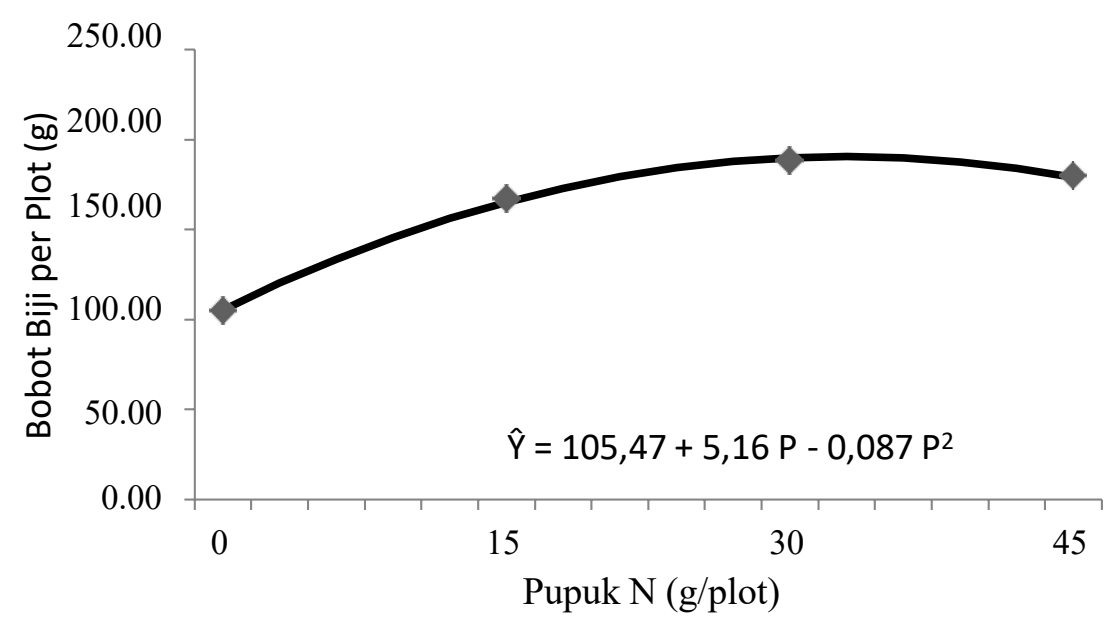

Gambar 7. Respon Bobot Biji per Plot Tanaman Kedelai terhadap Perlakuan Pupuk N 
Gambar 7 terlihat bahwa respon antara pupuk $\mathrm{N}$ dengan bobot biji per plot tanaman kedelai adalah kuadratik. Artinya, bobot biji per plot tanaman kedelai akan mengalami peningkatan hingga dosis 33,097 g pupuk $\mathrm{N}$ yang diberikan, setelah melebihi dosis tersebut maka bobot biji per plot akan menurun kembali. Kurva respon bobot biji per plot tanaman kedelai terhadap perlakuan pupuk kandang sapi dapat dilihat pada Gambar 8.

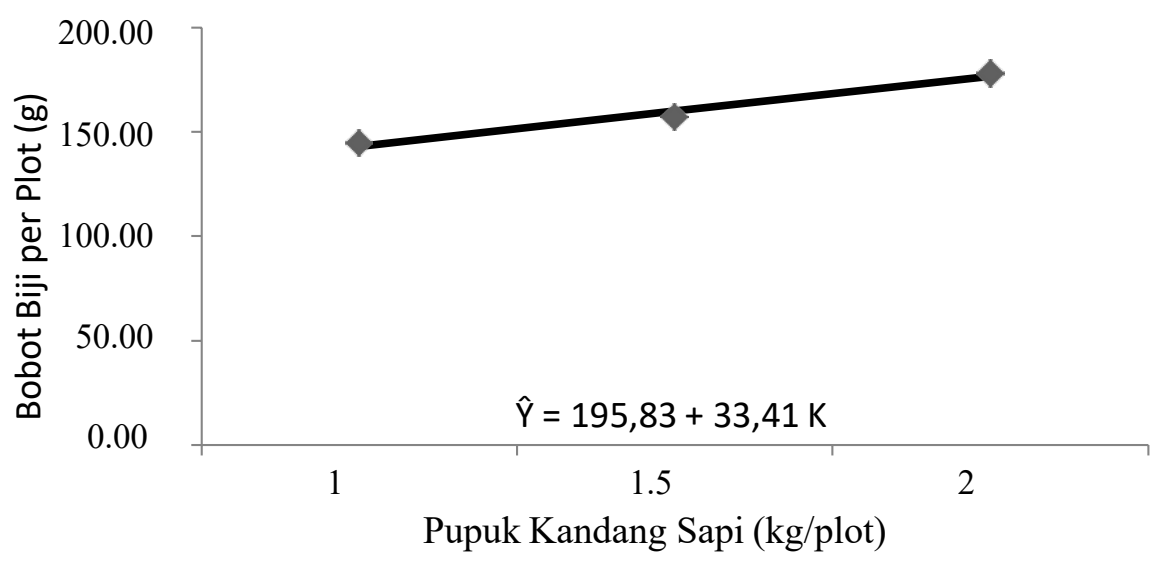

Gambar 8. Respon Bobot Biji per Plot Tanaman Kedelai terhadap Perlakuan Pupuk Kandang Sapi

Respon antara pupuk kandang sapi dengan bobot biji per plot tanaman kedelai adalah linier positif (Gambar 8). Artinya, bobot biji per plot tanaman kedelai akan mengalami peningkatan sejalan dengan semakin meningkatnya pupuk kandang sapi yang diberikan.

\section{Bobot 100 Biji (g)}

Pupuk $\mathrm{N}$ berpengaruh nyata terhadap bobot 100 biji tanaman kedelai. Perlakuan pupuk kandang sapi berpengaruh tidak nyata terhadap bobot 100 biji tanaman kedelai. Interaksi antara pupuk $\mathrm{N}$ dan pupuk kandang sapi berpengaruh tidak nyata terhadap bobot 100 biji tanaman kedelai (Tabel 7).

Tabel 7. Uji Beda Rataan Bobot 100 Biji Tanaman Kedelai akibat Perlakuan Pupuk N dan Pupuk Kandang Sapi

\begin{tabular}{lccccc}
\hline Perlakuan & \multicolumn{5}{c}{ Pupuk N } \\
\hline Pukan Sapi & P0 & P1 & P2 & P3 & Rataan \\
K1 & 14.03 & 14.73 & 14.97 & 15.03 & 14.69 \\
K2 & 14.33 & 14.77 & 15.10 & 15.07 & 14.82 \\
K3 & 14.63 & 14.83 & 15.23 & 15.13 & 14.96 \\
\hline Rataan & $14.33 \mathrm{c}$ & $14.78 \mathrm{~b}$ & $15.10 \mathrm{a}$ & $15.08 \mathrm{a}$ \\
\hline
\end{tabular}

Keterangan: Angka yang diikuti oleh huruf yang sama pada kolom yang sama berbeda tidak nyata pada taraf $\alpha=0.05$ berdasarkan uji jarak Duncan

Pengaruh perlakuan pupuk $\mathrm{N}$ terhadap bobot 100 biji tanaman kedelai diperoleh rataan terberat terdapat pada perlakuan $\mathrm{P} 2$ berbeda nyata dengan $\mathrm{P} 0$ dan $\mathrm{P} 1$ tetapi 
berbeda tidak nyata dengan P3. Pengaruh perlakuan pupuk kandang sapi terhadap bobot 100 biji tanaman kedelai diperoleh rataan terberat pada perlakuan K3. Kurva respon bobot 100 biji tanaman kedelai erhadap perlakuan pupuk $\mathrm{N}$ dapat dilihat pada Gambar 9.

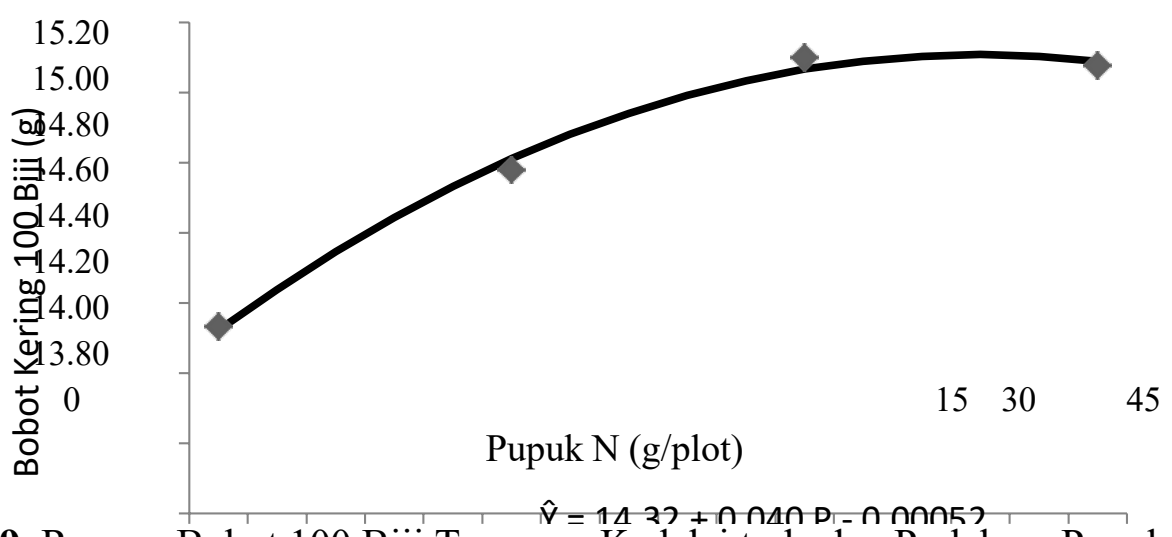

Gambar 9. Respon Bobot 100 Biji Tanaman Kedelai terhadap PerlakuanPupuk N

Respon antara pupuk $\mathrm{N}$ dengan bobot 100 biji tanaman kedelai adalah kuadratik (Gambar 9). Artinya, bobot 100 biji tanaman kedelai akan mengalami peningkatan hingga dosis 38,82 g pupuk $\mathrm{N}$ yang diberikan, setelah melebihi dosis tersebut maka bobot 100 biji akan menurun kembali. Hal ini diduga ukuran biji dipengaruhi oleh besarnya fotosintat yang dihasilkan oleh tanaman untuk didistribusikan ke biji. Peningkatan berat 100 biji kering per tanaman menunjukkan bahwa fotosintat yang dihasilkan dari proses fotosintesis yang dilakukan oleh daun yang kemudian didistribusikan ke biji untuk pembesaran biji lebih banyak dibandingkan tanpa pemberian pupuk urea. Hal ini tentunya berkaitan dengan penyerapan unsur nitrogen yang dilakukan oleh tanaman baik dalam perannya untuk pembentukan klorofil maupun pertumbuhan ukuran daunnya. Unsur nitrogen salah satunya berperan dalam pembentukan dan pertumbuhan organ-organ vegetatif yaitu batang, daun, dan akar (Mayani \& Hapsoh, 2013)

Pemupukan $\mathrm{N}$ dengan dosis yang tinggi dapat memperlambat dan mengurangi jumlah $\mathrm{N}$ yang tertambat. Kandungan nitrogen tanah atau pemupukan $\mathrm{N}$ yang terlalu tinggi dapat menghambat pembentukan bintil dan mengurangi jumlah $\mathrm{N}$ yang tertambat, untuk mendapatkan tingkat hasil kedelai yang tinggi diperlukan hara nitrogen dalam jumlah yang cukup dan seimbang (Sari, Puspitorini, \& Kurniastuti, 2016).

Pupuk kandang sapi berpengaruh nyata terhadap jumlah polong hampa per sampel, bobot biji per sampel dan bobot biji per plot tetapi berpengaruh tidak nyata terhadap tinggi tanaman, umur berbunga, jumlah polong berisi per sampel dan bobot 100 biji. Pemberian pupuk kandang sapi berpengaruh nyata terhadap jumlah polong hampa per sampel, bobot biji per sampel dan bobot biji per plot. Hal ini dikarenakan dalam pemberian pupuk kandang terjadi proses penguraian bahan- bahan organik di dalam tanah oleh mikroorganisme yang dapat memperbaiki sifat biologi tanah dan memperbaiki struktur tanah. Struktur tanah yang baik memungkinkan udara dapat masuk kedalam tanah sehingga aerasi 
tanah optimal. Penguraian yang terjadi akibat pemberian pupuk kandang dapat mempertinggi kadar humus, dimana dapat memperbaiki struktur tanah, menjadikan tanah lebih mudah diolah dan menyediakan oksigen dalam jumlah yang cukup. Pupuk kandang juga dapat mengembangkan kehidupan mikroorganisme (jasad renik) dalam tanah. Jasad renik sangat penting bagi kesuburan tanah karena serasah dan sisa-sisa tanaman dapat diubah menjadi humus yang dapat meningkatkan daya penahan air sehingga memudahkan akarakar tanaman menyerap zat makanan bagi pertumbuhan dan perkembangannya (Hartatik \& Widiowati, 2010).

Pertumbuhan yang didefinisikan sebagai pertambahan berat dan besar tanaman sebagai akibat adanya pembentukan unsurunsur struktural yang baru, sangat dipengaruhi oleh ketersediaan unsur hara dan ketersediaan unsur hara berhubungan terutama dengan pengaruh dari proses perombakan pupuk kandang yang terjadi, dimana pada proses perombakan pupuk kandang tersebut sangat dipengaruhi oleh aktivitas mikroorganisme didalam tanah (Jaipaul, Sanjeev, \& Sharma, 2011). Penambahan pupuk kandang kedalam tanah selain meningkatkan jumlah dan aktivitas mikroorganisme tanah, juga dapat menyediakan unsur hara bagi tanaman, mempertinggi humus, memperbaiki struktur tanah dan memiliki daya jerap kation yang lebih besar daripada koloid liat sehingga dapat meningkatkan nilai KTK (Borchartt, Jakelaitis, Valadão, Venturoso, \& Santos, 2011). Tanah yang porous akibat penambahan bahan organik mendukung perkembangan akar menembus masuk ke dalam tanah dan akar menyerap hara semakin banyak sehingga dapat mendukung pertumbuhan. Peningkatan nilai KTK pada pemberian pupuk kandang mengakibatkan tanah mampu menjerap dan menyediakan unsur hara. Kondisi tanah yang porous maka aerasi di dalam tanah menjadi baik, akar mempertukarkan gas dengan ruang udara tanah dengan memasukkan $\mathrm{O}_{2}$ dan membebaskan $\mathrm{CO}_{2}$. Pertukaran gas mendukung respirasi seluler sel-sel akar sehingga air dan mineral dapat terangkut dari akar menuju sistem tunas.

Kandungan unsur hara yang ada di dalam pupuk kandang bermanfaat untuk merangsang pertumbuhan tanaman. Pemberian pupuk kandang dapat meningkatkan kemampuan tanah menahan air, merangsang granulasi, memantapkan agregat tanah, menurunkan plastisitas dan kohesi tanah. Pemberian pupuk kandang juga mampu meningkatkan KTK tanah, mengikat unsur $\mathrm{N}, \mathrm{P}, \mathrm{S}$ dalam bentuk organik sehingga terhindar dari pencucian, melarutkan sejumlah unsur, meningkatkan jumlah dan aktivitas mikroorganisme tanah. Penggunaan pupuk kandang dapat memperbaiki kesuburan tanah dan meningkatkan efesiensi penggunaan pupuk anorganik, sehingga mempercepat pertumbuhan tanaman. Pupuk kandang dapat memperbaiki permeabilitas tanah, porositas, struktur tanah, daya menahan air dan kandungan kation tanah. Berdasarkan peranannya maka pupuk kandang ayam mempunyai 3 peran penting, yaitu: (1) Memperbaiki sifat fisik tanah, seperti meningkatkan kemampuan menahan air, memantapkan agregat dan struktur tanah serta memperbaiki aerasi tanah, (2) Memperbaiki sifat kimia tanah seperti kemampuan tanah dalam tukar kation, ketersediaan unsur hara bagi tanaman (Zainal, Nugroho, \& Suminarti, 2014). Sifat bahan organik dan anorganik yaitu memperbaiki struktur tanah dan penyedia unsur hara yang dilepas secara bertahap. Hal ini disebabkan unsur hara didalam 
tanah masih terikat dalam senyawa yang kompleks yang tidak dapat diserap langsung oleh tanaman.

\section{KESIMPULAN}

1. Pupuk N dengan dosis $30 \mathrm{~g} / \mathrm{plot}$ berpengaruh nyata terhadap tinggi tanaman, jumlah polong hampa per sampel, jumlah polong berisi per sampel, bobot biji per sampel, bobot biji per plot dan bobot 100 biji tetapi berpengaruh tidak nyata terhadap umur berbunga.

2. Pupuk kandang sapi berpengaruh nyata terhadap jumlah polong hampa per sampel, bobot biji per sampel dan bobot biji per plot tetapi berpengaruh tidak nyata terhadap tinggi tanaman, umur berbunga, jumlah polong berisi per sampel dan bobot 100 biji.

3. Interaksi pupuk $\mathrm{N}$ dan pupuk kandang sapi berpengaruh tidak nyata terhadap tinggi tanaman, umur berbunga, jumlah polong hampa per sampel, jumlah polong berisi per sampel, bobot biji per sampel, bobot biji per plot dan bobot 100 biji.

\section{DAFTAR PUSTAKA}

Borchartt, L., Jakelaitis, A., Valadão, F. C. de A., Venturoso, L. A. C., \& Santos, C. L. dos. (2011). Períodos de interferência de plantas daninhas na cultura do feijoeiro-comum (Phaseolus vulgaris L.). Revista Ciência Agronômica, 42(3), 725-734.

Ditjen Tanaman Pangan. (2013). Pedoman Teknis Pengelolaan Tanaman Kedelai. Bogor: Direktorat Jendral Tanaman Pangan.

Fachruddin, L. (2000). Bercocok Tanam dan Pascapanen Kacang-kacangan. Jakarta: PT. Indica.

Hartatik, W., \& Widiowati, L. R. (2010). Pupuk Kandang. Bogor.

Jaipaul, J., Sanjeev, S., \& Sharma, A. K. (2011). Effect of organic fertilizers on growth, yield and quality of potato under rainfed conditions of central
Himalayan region of Uttarakhand. Potato Journal, 38(2), 176-181.

Mayani, N., \& Hapsoh, H. (2013). Potensi Rhizobium dan Pupuk Urea untuk Meningkatkan Produksi Kedelai (Glycine max L.) pada Lahan Bekas Sawah. KULTIVAR, 5(2).

Melati, M., \& Andriyani, W. (2005). Pengaruh pupuk kandang ayam dan pupuk hijau Calopogonium mucunoides terhadap pertumbuhan dan produksi kedelai panen muda yang dibudidayakan secara organik. Jurnal Agronomi Indonesia (Indonesian Journal of Agronomy), 33(2).

Novriani. (2011). Peranan Rhizobium dalam Meningkatkan Ketersediaan Nitrogen bagi Tanaman Kedelai. Agronobis, 3(5), 35-42.

Nurherliani, N., Ningsih, S. S., \& Mawarni, R. (2019). PENGARUH PEMBERIAN PUPUK KANDANG KAMBING DAN NITROGEN TERHADAP PERTUMBUHAN DAN PRODUKSI TANAMAN KACANG KEDELAI (Glycine max L.). Bernas: Jurnal Penelitian Pertanian, 15(2), 75-83.

Permadi, K., \& Haryati, Y. (2015). No Title. Pemberian Pupuk N, P, Dan K Berdasarkan Pengelolaan Hara Spesifik Lokasi Untuk Meningkatkan Produktivitas Kedelai, 5(1), 1-8.

Purbajanti, E. D., \& Kusmiyati, F. (2013). Response of Indonesian tropical legumes to PEG 6000 drought stress. Journal of Biology, Agriculture and Healthcare, 3(15), 115-121.

Rodina, N. (2014). Pengaruh Pemberian Pupuk Kotoran Sapi Terhadap Pertumbuhan Tanaman Jagung (Zea Mays L.) Pada Tanah Humus. Sekolah Tinggi Ilmu Pertanian Amuntai.

Rohmah, E. A. (2016). Analisis Pertumbuhan Tanaman Kedelai (Glycine max L.) Varietas Grobogan Pada Perlakuan Cekaman Genangan. Institut Teknologi Sepuluh Nopember. Sari, E. F., Puspitorini, P., \& Kurniastuti, T. (2016). PENGARUH PEMBERIAN LEGIN DAN PUPUK UREA 


\section{TERHADAP PERTUMBUHAN DAN}

HASIL TANAMAN KEDELAI

(Glycine max (L.) Merril). VIABEL:

Jurnal Ilmiah Ilmu-Ilmu Pertanian, 10(1), 20-36.

Triyono, K. (2013). Keanekaragaman hayati dalam menunjang ketahanan pangan. Jurnal Inovasi Pertanian, 11(1), 12-22.

Zainal, M., Nugroho, A., \& Suminarti, N. E. (2014). Respon pertumbuhan dan hasil tanaman kedelai (Glycine max (L.) Merill) pada berbagai tingkat pemupukan $\mathrm{N}$ dan pupuk kandang ayam. Jurnal Produksi Tanaman, 2(6). 